\title{
IMPLEMENTASI AKAD QARDH DAN MURABAHAH DALAM PENGALIHAN PEMBIAYAAN (Studi Kasus pada PT. BPRS Mandiri Mitra Sukses Gresik)
}

\author{
Miftahul Husnah \\ Sentot Imam Wahjono \\ Email: bundamiftah177@gmail.com
}

\begin{abstract}
Researcher wanted to examine in detail the implementation of qardh and murabahah agreement in the transfer of financing (take over) conducted by PT. BPRS Mandiri Mitra Sukses Gresik Indonesia, to answer the question : How the implementation of qardh and murabahah agreement on the transfer financing practices in BPRS Mandiri Mitra Sukses Gresik ?, What is the difference of the implementation of qardh and murabahah agreement on the transfer financing practices in BPRS Mandiri Mitra Sukses Gresik ?, What are the constraints and supporting factors in the implementation of qardh and murabahah agreement?

In answering these problems used the type of qualitative research. The data collection techniques used in this study through methods of observation, interview (interview), and documentation. The data collected was compiled and analyzed using inductive thinking namely the mindset based on the facts in the field about the practice of taking over between the Conventional Financial Institution (LKK) and the bank of the Sharia Financial Institution (LKS), then linked with the qardh and murabahah theory in application take over.

The result of the research that in the implementation of qardh and murabahah agreement in the transfer of financing with the purpose of taking over or transfer of financing at Bank Partners Syariah that is by the customer coming to Bank Partners Sharia to apply for taking over financing.

The constraints of the implementation of qardh and murabahah agreement included the possibility of bad debts from customers and the history of customer data in SID BI that sometimes can hamper the implementation of taking over. While the supporting factors in the implementation of qardh and murabahah agreement included many fanatic customers to sharia, thus increasing the number of customers used sharia bank services, the products provided in the form of additional business capital, and ease of payment.
\end{abstract}

Key words: utang piutang, take over, akad, the economic laws of Sharia.

\section{PENDAHULUAN}

Pembiayaan dalam kegiatan

Perbankan syariah merupakan kegiatan usaha yang paling utama, karena pendapatan terbesar dari usaha Bank syariah berasal dari pendapatan kegiatan usaha pembiayaan yaitu berupa bagi hasil. Ruang lingkup dari pembiayaan sebagai kegiatan Perbankan syariah tidaklah sematamata berupa kegiatan membelikan barang modal yang diperuntukkan nasabah melainkan sangatlah kompleks karena menyangkut keterkaitan unsur-unsur yang 
cukup banyak, diantaranya meliputi: sumber-sumber dana pembiayaan, alokasi dana, organisasi dan manajemen pembiayaan, kebijakan pembiayaan, dokumentasi dan administrasi pembiayaan, pengawasan serta penyelesaiaan pembiayaan yang bermasalah.

Mengingat begitu luas ruang lingkup dan unsur-unsur yang melingkupi kegiatan pembiayaan ini, maka tidak berlebihan penanganannya pun harus dilakukan secara sangat hati-hati dengan ditunjang profesionalisme serta integritas moral yang harus melekat pada sumber daya manusia pembiayaan tersebut. Bank Syariah saat ini menjadi salah satu alternatif masyarakat untuk melakukan transaksi perbankan dan transaksi bisnis para pengusaha, di mana hal ini dapat dilihat dengan semakin pesatnya pertumbuhan bank syariah. Secara yuridis formal, keberadaan bank syariah telah diakui dalam sistem perundang-undangan Negara Republik Indonesia, termasuk keberadaan Bank Pembiayaan Rakyat Syariah. Dalam ketentuan Pasal 1 angka 3 dan 4, Undangundang Nomor 10 Tahun 1998 tentang Perubahan Undang-undang Nomor 7 Tahun 1992 tentang Perbankan (selanjutnya disebut dengan Undang-undang Perbankan), disebutkan, bahwa undang-undang membagi jenis bank menjadi dua macam, yaitu bank umum dan bank perkreditan rakyat.

Bank umum adalah bank yang melaksanakan kegiatan usaha secara konvensional dan/atau berdasarkan Prinsip Syariah yang dalam kegiatannya memberikan jasa dalam lalu lintas pembayaran; Bank perkreditan rakyat adalah bank yang melaksanakan kegiatan usaha secara konvensional atau berdasarkan Prinsip Syariah yang dalam kegiatannya tidak memberikan jasa dalam lalu lintas pembayaran.

Sistem perbankan dengan prinsip syariah istilah kredit berubah menjadi istilah pembiayaan. Hal ini dapat dilihat dalam ketentuan Pasal 1 angka 12 Undang-undang Nomor 10 Tahun 1998 tentang Perbankan yang menyebutkan : Pembiayaan berdasar Prinsip Syariah adalah penyediaan uang atau tagihan yang dipersamakan dengan itu berdasarkan persetujuan atau kesepakatan antara bank dengan pihak lain yang mewajibkan pihak yang dibiayai untuk mengembalikan uang atau tagihan tersebut setelah jangka waktu tertentu dengan imbalan atau bagi hasil.

Prinsip syariah oleh Pasal 1 angka 12 Undang-undang Nomor 21 Tahun 2008 tentang Perbankan Syariah (selanjutnya disebut dengan Undang-undang Perbankan Syariah) diberikan defenisi yaitu: prinsip hukum Islam dalam kegiatan perbankan berdasarkan fatwa yang dikeluarkan oleh lembaga yang memiliki kewenangan dalam penetapan fatwa di bidang syariah.

Sehubungan dengan hal tersebut di atas, PT. BPRS Mandiri Mitra Sukses Gresik juga turut membantu debitur atau calon debitur yang sebelumnya 
mengagunkan atau menjaminkan asetnya di bank konvensional, kemudian mengambil alih pinjaman tersebut yang sebelumnya berbasis riba pada bank konvensional kini diakadi dengan akad-akad syariah yaitu akad murabahah dan qardh.

\section{KAJIAN TEORI}

\section{A. Utang Piutang (Qardh)}

1. Pengertian Piutang $($ Qardh $)$

Istilah Arab yang sering digunakan untuk utang piutang adalah al-dayn (jamaknya alduyu>n) dan qardh. Dalam pengertian yang umum, utang piutang mencakup transaksi jual-beli dan sewa-menyewa yang dilakukan secara tidak tunai (kontan). Transaksi seperti ini dalam fikih dinamanakan muda>yanah dan tada> yun. ${ }^{1}$

Sebagai sebuah transaksi yang bersifat khusus, istilah yang lazim dalam fikih untuk transaksi utang piutang khusus ini adalah qardh.Secara bahasa, qardh berarti al-qath. Harta yang diberikan kepada orang yang meminjam (debitur) disebut qardh, karena merupakan "potongan" dari harta yang memberikan pinjaman (kreditur). ${ }^{2}$

Secara istilah, menurut Hanafiyah qardh adalah harta yang memiliki kesepadanan

${ }^{1}$ Ghufron A. Masadi, Fiqh Muamalah Kontekstual, (Jakarta: PT. Raja Grafindo Persada, 2002) 169.

${ }^{2}$ Wahbah az-Zuhaili>,Fiqh Isla $>m$ wa Adillatuhu, terj. Abdul Hayyie al-Kattani, Jilid 5 (Jakarta: Gema Insani, 2011), 373. yang Anda berikan untuk Anda tagih kembali. Atau dengan kata lain, suatu transaksi yang dimaksudkan untuk memberikan harta yang memiliki kesepadanan kepada orang lain untuk dikembalikan yang sepadan dengan itu. ${ }^{3}$

\section{B. MURABAHAH}

\section{Pengertian Murabahah}

Murabahah merupakan salah satu sistem akad jual beli. Secara bahasa, murabahah berasal dari kata ribh yang bermakna tumbuh dan berkembang dalam perniagaan. Dalam istilah syariah, terdapat berbagai definisi mengenai konsep murabahah yang berbedabeda, diantaranya:

a. Murabahah adalah persetujuan jual beli suatu barang dengan sebesar harga pokok yang ditambah dengan keuntungan yang disepakati bersama dengan pembayaran yang ditangguhkan satu bulan atau satu tahun. ${ }^{4}$

b. Murabahah adalah suatu kontrak penjualan dengan kenaikan atas harga yang disetujui oleh dua pihak. ${ }^{5}$

c. Murabahah adalah akad jual beli barang dengan

\footnotetext{
${ }^{3}$ Ibid, 374.

${ }^{4}$ Warkum Sumitro, Asas-Asas Perbankan Islam dan Lembaga-Lembaga Terkait di Indonesia, (Jakarta: Raja Grafindo Persada, 1997), 37.

${ }^{5}$ Veithzal Rivai et al., Islamic Transaction Law in Business, (Jakarta: Bumi Aksara, 2011), 257.
} 
menyatakan harga perolehan dan keuntungan (margin) yang disepakati oleh penjual dan pembeli. ${ }^{6}$

d. Murabahah merupakan salah satu bentuk jual beli yang mengharuskan penjual memberikan informasi kepada pembeli tentang biaya-biaya yang dikeluarkan untuk mendapatkan komoditas (harga pokok pembelian) dan tambahan profit yang diinginkan yang tercermin dalam harga jual. ${ }^{7}$

e. Murabahah adalah suatu bentuk jual beli tertentu ketika penjual menyatakan biaya perolehan barang, meliputi harga barang dan biaya-biaya lain yang dikeluarkan untuk memperoleh barang tersebut, dan tingkat keuntungan (margin) yang diinginkan. ${ }^{8}$

Berdasarkan pada beberapa uraian tentang pengertian murabahah di atas, dapat disimpulkan bahwa murabahah adalah salah satu bentuk akad jual beli suatu barang yang mengharuskan penjual menyatakan harga pokok barang ditambah keuntungan yang diinginkannya kepada pembeli,

${ }^{6}$ Adiwarman A. Karim, Bank Islam; Analisis Fiqih dan Keuangan, cet. VIII(Jakarta: PT. Raja Grafindo Persada, 2011), 113.

${ }^{7}$ Ismail Nawawi, Fikih Muamalah Klasik dan Kontemporer,(Bogor: Ghalia Indonesia, 2012), 91.

${ }^{8}$ Ascarya, Akad dan Produk Bank Syari'ah, (Jakarta: Rajawali Pers, 2013), 82. disertai dengan kesepakatan pembayaran yang ditangguhkan sesuai dengan waktu yang telah disepakati bersama.

\section{TAKE OVER}

1. Take Over dalam Lembaga Keuangan Syariah

Salah satu bentuk jasa pelayanan Lembaga Keuangan Syariah (LKS) adalah membantu masyarakat untuk mengalihkan transaksi non syariah yang telah berjalan menjadi transaksi yang sesuai dengan syariah. Dalam hal ini, atas permintaan nasabah, bank syariah melakukan pengambilalihan hutang nasabah di Lembaga Keuangan Konvensional (LKK) dengan memberikan jasa hiwalah atau dapat juga menggunakan qardh. Disesuaikan dengan ada atau tidaknya unsur bunga dalam hutang tersebut.

Take over yang demikian itu diatur oleh Dewan Syariah Nasional dalam fatwa DSN-MUI Nomor 31/DSN-MUI/VI tahun 2002 yang disebut juga dengan pengalihan hutang. Take over yang dimaksud adalah proses pemindahan kredit nasabah di LKK menjadi pembiayaan dengan prinsip jual beli yang berdasarka syariah.

Dalam lingkup perbankan syariah, yang dimaksud dengan pembiayaan take over (pengalihan hutang) adalah pembiayaan yang 
timbul sebagai akibat dari take over terhadap transaksi non syariah yang telah berjalan yang dilakukan oleh bank syariah atas permintaan nasabah. $^{9}$

\section{ANALISIS HASIL PENELITIAN}

A. Pelaksanaan Akad Qardh dan Murabahah pada Praktik Pengalihan Pembiayaan di BPRS Mandiri Mitra Sukses Gresik

Take over yang dimaksud dalam pembahasan skripsi ini adalah take over menurut Dewan Syariah Nasional Nomor 31/DSNMUI/VI 2002, yang disebut juga dengan pengalihan hutang. Pengalihan hutang adalah pemindahan utang nasabah dari bank atau lembaga keuangan konvensional ke bank atau lembaga keuangan syariah.

Berdasarkan fatwa tersebut konsep pengalihan hutang terbagi menjadi empat alternatif:

1. Alternatif pertama

Pada alternatif pertama ini lembaga keuangan syariah (LKS) memberikan qardh kepada nasabah yang kemudian digunakan oleh nasabah untuk melunasi (kredit) hutangnya pada lembaga keuangan konvensional (LKK) dan dengan kemudian asset yang telah dibeli nasabah menjadi miliknya secara penuh. Kemudian nasabah menjual assetnya kepada Lembaga Keuangan Syariah (LKS) dan dengan hasil penjualan itu

${ }^{9}$ Adiwarman A. Karim, Bank Islam : Analisis Fiqih dan Keuangan (Jakarta: Raja Grafindo Persada, 2006), 248. nasabah melunasi qardh-nya kepada Lembaga Keuangan Syariah (LKS). Lalu Lembaga Keuangan Syariah (LKS) menjual secara murabahah assetyang telah menjadi miliknya tersebut kepada nasabah dengan pembayaran secara angsuran.

Pada alternatif pertama ini Fatwa DSN Nomor 04//DSN-MUI/IV/2001

tentang qard dan Fatwa DSN Nomor 04/DSN-MUI/IV/2000 tentang murabahah berlaku dalam pelaksanaan pembiayaan pengalihan hutang.

2. Alternatif kedua

Pada alternatif kedua ini Lembaga Keuangan Syariah (LKS) membeli sebagian asset nasabah dengan seizin lembaga keuangan konvensional (LKK) sehingga dengan demikian terjadilah Syirkah al-milk antara Lembaga Keuangan Syariah (LKS) dan nasabah atas asset nasabah tersebut. Asset yang telah dibeli nasabah ini adalah bagian assetyang senilai dengan hutang (sisa angsuran) nasabah kepada lembaga keuangan konvensional (LKK). Kemudian Lembaga Keuangan Syariah (LKS) menjual secara murabahah bagian assetyang menjadi miliknya kepada nasabah, dengan pembayaran angsuran. Pada alternatif kedua ini Fatwa DSN Nomor 04/DSNMUI/IV/2000 tentang murabahah berlaku dalam 
pelaksanaan pembiayaan pengalihan hutang.

3. Alternatif ketiga

Pada alternatif ketiga ini dalam pengurusan untuk memperoleh kepemilikan penuh atas asset nasabah dapat melakukan akad ijarah dengan Lembaga Keuangan Syariah (LKS) sesuai dengan Fatwa DSN Nomor 09/DSNMUI/IV/2002. Dan apabila diperlukan LKS dapat membantu menalangi kewajiban nasabah dengan menggunakan akad qardh sesuai dengan Fatwa DSN Nomor 19/DSN-MUI/IV2001. Kemudian akad ijarah yang digunakan oleh bank harus terpisah dari pemberian talangan yang berdasarkan akad qardh tersebut. Besarnya imbalan jasa ijarah tidak boleh berdasarkan pada jumlah talangan yang diberikan Lembaga Keuangan Syariah (LKS) kepada nasabah.

4. Alternatif keempat

ini Lada alternatif keempat Syariah (LKS) memberikan qardh kepada nasabah yang kemudian digunakan oleh nasabah untuk melunasi kredit hutangnya pada lembaga keuangan konvensional (LKK), dan dengan demikian asset yang telah dibeli nasabah menjadi miliknya secara penuh. Kemudian nasabah menjual assetnya kepada Lembaga Keuangan Syariah (LKS) dan dengan hasil penjualan itu nasabah melunasi qardh nya kepada
Lembaga Keuangan Syariah

(LKS). Lalu Lembaga

Keuangan Syariah (LKS) menyewakan asset tersebut kepada nasabah dengan akad ijarah muntahiyah bi tamlik.

Pada alternatif keempat

ini fatwa DSN Nomor

27/DSN-MUI/III/2002 tentang al-ijarah al-muntahiyah bi altamlik berlaku pula dalam pelaksanaan pembiayaan pengalihan hutang.

Dari keempat alternatif akad tersebut BPRS Mandiri Mitra Sukses menggunakan alternatif yang pertama yakni menggunakan kombinasi akad Qardh yaitu dengan qardh kepada nasabah yang kemudian digunakan oleh nasabah untuk melunasi (kredit) hutangnya pada lembaga keuangan konvensional (LKK) dan dengan kemudian asset yang telah dibeli nasabah menjadi miliknya secara penuh. Kemudian nasabah menjual assetnya kepada Lembaga Keuangan Syariah (LKS) dan dengan hasil penjualan itu nasabah melunasi qardh-nya kepada Lembaga Keuangan Syariah (LKS). Lalu Lembaga Keuangan Syariah (LKS) menjual secara murabahah asset yang telah menjadi miliknya tersebut kepada nasabah dengan pembayaran secara angsuran dengan menggunakan akad murabahah berlaku dalam pelaksanaan pembiayaan pengalihan hutang
B. Perbedaan Pelaksaan Akad Qardh dan Murabahah pada Praktik Pengalihan Pembiayaan di Perbankan Syariah 
Akad qardh dan murabahah yang digunakan dalam praktik pengalihan pembiayaan dari bank konvensional ke bank syariah di BPRS Mandiri Mitra Sukses Gresik tidak jauh berbeda dengan akad qardh dan murabahah yang digunakan dalam praktik pembiayaan-pembiayaan yang lain. Meskipun demikian tentunya masih terdapat beberapa perbedaan dalam pelaksanaannya yang perlu kita cermati. Adapun berbedaanperbedaan tersebut diantaranya meliputi:

Akad qardh untuk pembiayaan pada umumnya digunakan sebagai dana talangan Al-qardh merupakan salah satu jenis produk pembiayaan pada Lembaga Keuangan Syariah (LKS) atau perbankan syariah. Pembiayaan qardh merupakan pembiayaan khusus yang membutuhkan sumber dana tersendiri. Sumber dana untuk pembiayaan ini antara lain dari bagian modal yang dialokasikan khusus ataupun dari dana zakat, infaq, dan shadaqah. Oleh karena itu, pembiayaan ini biasanya diarahkan untuk pihak-pihak yang sangat membutuhkan seperti fakir miskin yang ingin berusaha, dan lain-lain. Dari produk pembiayaan ini lebih berkarakter sosial daripada ekonomis.

Mengingat bahwa peruntukannya adalah bagi pengusaha kecil yang memiliki kelemahan profesionalisme, maka biasanya sistem pelunasan yang ditetapkan adalah harian, bukannya bulanan. Hal ini untuk menghindari resiko pemanfaatan dana untuk selain usaha (side streaming).
Namun demikian bank harus memiliki program pembiayaan yang jelas dan efektif agar nasabah yang bersangkutan tidak selamanya berusaha dalam skala kecil.

Pembiayaan tersebut sejalan dengan akad qardh yang digunakan sebagai dana talangan atau take over antara bank syariah dengan bank konvensional, dana ini digunakan oleh nasabah dalam hitungan hari, setelah hutang berhasil di take over maka nasabah diakad dengan akad baru yaitu akad murabahah. Namun disini penulis kurang setuju dengan pengaplikasikan dua akad ini, karena hemat penulis akad qardh ini merupakan utang piutang yang penyerahan harta berupa uang untuk dikembalikan pada waktunya dengan nilai yang sama. Namun jika pengembaliannya kepada bank yang menalangi harus dengan menggunakan akad lain, seperti murabahah pada paraktik ini, maka secara otomatis nasabah mengembalikan dana talangan atau take over dengan jumlah yang berbeda yaitu dana pokok ditambah dengan margin.

Secara umum modal dalam pembiayaan murabahah dapat diartikan sebagai biaya yang harus dikeluarkan oleh pembeli pertama untuk mendapatkan barang atau uang yang dijadikan objek murabahah. Modal yang dimaksud tidak hanya terdiri atas harga pokok pembelian saja. Namun, juga terdapat unsur lain yang dikeluarkan untuk mendapatkan barang tersebut, seperti misalnya biaya administrasi, biaya penilaian aset dan biaya roya pada sertifikat, serta biaya lainnya yang terkait 
dengan barang tersebut (overhead cost).

\section{KESIMPULAN}

Berdasarkan pada hasil penelitian dan analisis penelitian, dapat diambil kesimpulan sebagai berikut:

1. Pelaksanaan akad qardh dan murabahah pada pengalihan pembiayaan di Bank Mitra Syariah perlu memperhatikan beberapa hal, diantaranya:

a. Tujuan Nasabah melakukan take over didasari oleh alasan rasional dan emosional, hal ini boleh berdasarkan Surat Al-Baqarah ayat 168.

b. Pelunasan ke bank konvensional yang menggunakan akad qardh diperbolehkan karena qardh tidak terbatas alokasi penggunaannya.

c. Dana yang dibayarkan bank syariah kepada bank konvensional diikat dengan akad murabahah.

2. Perbedaan akad qardh dan murabahah pada praktik pengalihan pembiayaan di perbankan syariah meliputi: qardh dipakai untuk pelunasan kepada bank konvensional atau sebagai dana talangan sedangkan murabahah pada pembiayaan ini tergantung pada jenis pembiayaan yang dilakukan sebelum dilakukan take over.

3. Adapun kendala pelaksanaan akad qardh dan murabahah adalah kemungkinan kredit macet nasabah yang ada dalam riwayat data nasabah di SID BI, sehingga dapat menghambat take over. Sedangkan factor yang mendukung pelaksanaan akad qardh dan murabahah adalah banyak nasabah yang konsen terhadap syariah sehingga meningkatkan jumlah nasabah pengguna layanan bank syariah.

\section{DAFTAR PUSTAKA}

Ali, Zainuddin. Hukum Perbankan Syariah. Jakarta: Sinar Grafika, 2009.

Antonio, Muhammad Syafi'I, Bank Syariah: Dari Teori ke Praktik, Cet.1, Jakarta: Gema Insani, 2001

Asnawi, Faris Faulidi. Transaksi Bisnis E-Commerce Perspektif Islam. Yogyakarta: Magistra Insania Press, 2004.

Adrian Sutedi, Perbankan Syariah; Tinjauan dan Beberapa Segi Hukum, Bogor: Ghalia Indonesia, 2009

Ascarya, Akad dan Produk Bank Syari'ah, Jakarta: Rajawali Pers, 2013

(az) Zuhaili, Wahbah, Fiqh Islam wa Adillatuhu, terj. Abdul Hayyie alKattani, Jilid 5, Jakarta: Gema Insani, 2011

(al) Abbash, Abdullah bin Muhammad bin Ibrahim bin Uthman bin Khawasiti, Kitabu al-Musnaf fi al-Ahadith wa al-Athar, jilid 4, cet. I, Riyad: Maktabah al-Rusd, $1409 \mathrm{H}$ 
(al) Naysaburi Al-Imam Muslim bin al-Hajjaj al-Qashayri, Sahih Muslim, juz 5 Beirut: Dar al-Kutub al-'Ilmiyah, 1994

Basyir, Ahmad Azhar, Azaz-azaz Hukum Muamalah, Jogjakarta : Pn. Fakultas Hukum Univertas Islam, 1990

Djazuli, Kaidah-Kaidah Fikih,cet. I, Jakarta : Kencana, 2007, 130. Lihat juga, Moh. Adib Bisri, Terjemah al-Faraidul Bahiyyah Risalah Qawaid Fiqh, Kudus : Menara, 1977

Dewi, Gemala, Aspek-Aspek Hukum dalam Perbankan dan Perasuransian Syariah di Indonesia, Jakarta: Kencana, 2004

Departemen Agama RI, al-Qur'an dan Terjemahannya, Bandung: CV Penerbit Diponegoro, 2010

Departemen Agama RI, Mushaf Marwah; al-Quran, Terjemah, dan Tafsir untuk Wanita, Bandung: Penerbit Hilal, 2009 